\title{
Foliar Potassium Fertilizer Additives Affect Soybean Response and Weed Control with Glyphosate
}

\author{
Kelly A. Nelson, ${ }^{1}$ Peter P. Motavalli, ${ }^{2}$ William E. Stevens, ${ }^{3}$ John A. Kendig, \\ David Dunn, ${ }^{3}$ and Manjula Nathan ${ }^{5}$ \\ ${ }^{1}$ Division of Plant Science, Lee Greenley Jr. Memorial Research Center, University of Missouri, Novelty, MO 63460, USA \\ ${ }^{2}$ Department of Soil, Environmental and Atmospheric Science, University of Missouri, Columbia, MO 65211, USA \\ ${ }^{3}$ Division of Plant Science, University of Missouri, Portageville, MO 63873, USA \\ ${ }^{4}$ GBE Herbicide Field Testing Lead, Monsanto, Chesterfield, MO 63017, USA \\ ${ }^{5}$ Division of Plant Science, University of Missouri, Columbia, MO 65211, USA
}

Correspondence should be addressed to Kelly A. Nelson, nelsonke@missouri.edu

Received 12 August 2012; Accepted 25 September 2012

Academic Editor: Robert J. Kremer

Copyright (c) 2012 Kelly A. Nelson et al. This is an open access article distributed under the Creative Commons Attribution License, which permits unrestricted use, distribution, and reproduction in any medium, provided the original work is properly cited.

Research in 2004 and 2005 determined the effects of foliar-applied $\mathrm{K}$-fertilizer sources $\left(0-0-62-0\left(\% \mathrm{~N}-\% \mathrm{P}_{2} \mathrm{O}_{5}-\% \mathrm{~K}_{2} \mathrm{O}-\% \mathrm{~S}\right)\right.$, 0-0-25$17,3-18-18-0$, and 5-0-20-13) and additive rates $\left(2.2,8.8\right.$, and $\left.17.6 \mathrm{~kg} \mathrm{~K} \mathrm{ha}^{-1}\right)$ on glyphosate-resistant soybean response and weed control. Field experiments were conducted at Novelty and Portageville with high soil test $\mathrm{K}$ and weed populations and at Malden with low soil test $\mathrm{K}$ and weed populations. At Novelty, grain yield increased with fertilizer additives at $8.8 \mathrm{~kg} \mathrm{~K} \mathrm{ha}{ }^{-1}$ in a high-yield, weed-free environment in 2004, but fertilizer additives reduced yield up to $470 \mathrm{~kg} \mathrm{ha}^{-1}$ in a low-yield year (2005) depending on the $\mathrm{K}$ source and rate. At Portageville, K-fertilizer additives increased grain yield from 700 to $1160 \mathrm{~kg} \mathrm{ha}^{-1}$ compared to diammonium sulfate, depending on the $\mathrm{K}$ source and rate. At Malden, there was no yield response to $\mathrm{K}$ sources. Differences in leaf tissue $\mathrm{K}$ $(P=0.03), \mathrm{S}(P=0.03), \mathrm{B}(P=0.0001)$, and $\mathrm{Cu}(P=0.008)$ concentrations among treatments were detected $14 \mathrm{~d}$ after treatment at Novelty and Malden. Tank mixtures of K-fertilizer additives with glyphosate may provide an option for foliar K applications.

\section{Introduction}

Soybean (Glycine max (L.) Merr.) was produced on over 2 million hectares in Missouri and over $87 \%$ of the crop was planted to herbicide-resistant cultivars in 2004 [1]. Glyphosate-resistant cultivars allow farmers to apply glyphosate-based products for broad-spectrum post-emergence weed control. Similarly, more than $80 \%$ of U.S. soybean hectares are glyphosate resistant, which has saved farmers an estimated $\$ 1.2$ billion in production costs [2]. Spray additives have been utilized with glyphosate to enhance biological activity and overcome antagonism that salts cause in the spray carrier [3-5]. Potassium was one of the least antagonistic cations evaluated while few anions antagonized weed control with glyphosate [6]. Recent formulation developments include the introduced potassium salts of glyphosate [7-9]; therefore, the opportunity to utilize a potassiumbased fertilizer additive may have synergistic interactions.
Potassium is essential to plants, as it increases drought tolerance, stem strength, and plant growth. Potassium is made available to plants primarily by soil diffusion processes controlling $\mathrm{K}$ movement to the root surface. Soil water content is a key factor influencing the diffusion rate, and so drought conditions may result in limited $\mathrm{K}$ uptake. The incidence of $\mathrm{K}$ deficiency has increased in recent years for several reasons. These include reduced $\mathrm{K}$ availability under drought conditions, areas with compacted soil, reduced $\mathrm{K}$ fertilizer applications for soybean, the increased cost of $\mathrm{K}$ fertilizer, and increased $\mathrm{K}$ fertilizer requirements in cases of higher corn grain yields and increased soybean acreage in rotation with corn $[10,11]$. In soil test $\mathrm{K}$ data from the University of Missouri Soil and Plant Testing Laboratory, more than $50 \%$ of the samples were in the low to medium range [12]. These data indicate that nearly 1 million soybean hectares in Missouri either have been experiencing yield loss due to low $\mathrm{K}$ levels or could be at risk of yield loss. 
TABLe 1: Soil test values for Novelty, Portageville, and Malden in 2004 and 2005.

\begin{tabular}{|c|c|c|c|c|c|c|c|c|c|c|c|c|c|}
\hline \multirow[b]{2}{*}{ Site-year } & \multirow{2}{*}{$\begin{array}{c}\text { Soil } \\
\text { organic matter } \\
\left(\mathrm{g} \mathrm{kg}^{-1}\right)\end{array}$} & \multirow{2}{*}{$\begin{array}{c}\text { Cation } \\
\text { exchange capacity } \\
\left(\mathrm{cmol}_{\mathrm{c}} \mathrm{kg}^{-1}\right)\end{array}$} & \multirow[b]{2}{*}{$\mathrm{pH}\left(0.01 \mathrm{M} \mathrm{CaCl}_{2}\right)$} & \multirow[b]{2}{*}{ Bray $1 \mathrm{P}$} & \multirow{2}{*}{\multicolumn{2}{|c|}{$\begin{array}{c}\mathrm{K} \quad \mathrm{Ca} \\
\left(\mathrm{kg} \mathrm{ha}^{-1}\right)\end{array}$}} & \multicolumn{7}{|c|}{ Exchangeable (1 $\left.\mathrm{M} \mathrm{NH}_{4} \mathrm{AOc}\right)$} \\
\hline & & & & & & & $\mathrm{Mg}$ & $\mathrm{Cu}$ & $\mathrm{Fe}$ & $\begin{array}{l}\mathrm{Mn} \\
(\mathrm{mg} \\
\end{array}$ & $\begin{array}{c}\mathrm{B} \\
\left.\mathrm{kg}^{-1}\right)\end{array}$ & $\mathrm{SO}_{4}-\mathrm{S}$ & $\mathrm{Zn}$ \\
\hline \multicolumn{14}{|l|}{ Novelty } \\
\hline 2004 & 26 & 12.7 & 6.2 & 38 & 380 & 4,080 & 460 & 0.87 & 94.7 & 23.5 & 0.02 & 5.9 & 0.5 \\
\hline 2005 & 26 & 14.9 & 6.4 & 29 & 400 & 5,060 & 440 & 0.80 & 65.8 & 28.0 & 0.15 & 5.0 & 0.5 \\
\hline \multicolumn{14}{|c|}{ Portageville } \\
\hline 2004 & 17 & 8.3 & 5.7 & 76 & 390 & 1840 & 330 & 0.48 & 79.0 & 16.9 & 0.12 & 2.0 & 1.4 \\
\hline 2005 & 16 & 8.2 & 5.4 & 132 & 470 & 1450 & 260 & 0.75 & 89.6 & 21.3 & 0.13 & 0.7 & 1.1 \\
\hline \multicolumn{14}{|l|}{ Malden } \\
\hline 2004 & 8 & 4.2 & 5.9 & 101 & 281 & 1550 & 220 & 0.40 & 32.5 & 8.9 & 0.11 & 1.2 & $-^{\dagger}$ \\
\hline 2005 & 9 & 4.6 & 6.0 & 93 & 299 & 1320 & 240 & 0.33 & 35.6 & 7.7 & 0.13 & 1.9 & - \\
\hline
\end{tabular}

${ }^{\dagger}$ Data were not collected.

Several studies have evaluated soybean response to foliar fertilizer mixtures [13-18]. However, limited research has evaluated interactions between macronutrient foliar fertilizers and weed control with postemergence (POST) herbicides $[16,19,20]$. Combining a fertilizer source with a herbicide provides a practical opportunity to control weeds and fertilize the crop. A foliar application of $\mathrm{K}$ sulfate at 18 to $36 \mathrm{~kg} \mathrm{Kha}^{-1}$ when soybean was at the V4 and R1-R2 stages of development [21] increased yield from 400 to $750 \mathrm{~kg} \mathrm{ha}^{-1}$ compared to a nontreated or $\mathrm{MgSO}_{4}$ control; it also increased gross margins up to $\$ 18 /$ ha [22]. However, differences in commonly-recommended carrier volumes and herbicidefertilizer compatibility could limit the potential for coapplying $\mathrm{K}$ and glyphosate. When $\mathrm{K}$ fertilizer sources were evaluated for compatibility as the carrier with glyphosate, weed control was reduced when 0-0-25-17 (\%N-\% $\mathrm{P}_{2} \mathrm{O}_{5}-\% \mathrm{~K}_{2} \mathrm{O}-$ $\%$ S) and 5-0-20-13 were applied at 43 and $32 \mathrm{~kg} \mathrm{~K} \mathrm{ha}^{-1}$, respectively [20]. High application rates of 3-18-18-0 (30 $\left.\mathrm{kg} \mathrm{K} \mathrm{ha}^{-1}\right), \quad 0-0-25-17$ (43 $\left.\mathrm{kg} \mathrm{Kha}^{-1}\right)$, and 5-0-20-13 $\left(32 \mathrm{~kg} \mathrm{~K} \mathrm{ha}^{-1}\right.$ ) were a good source of $\mathrm{K}$ fertilizer, but were not economically feasible. The probability of an economical yield response increases if the fertilizer source is compatible with a postemergence herbicide such as glyphosate [16]. Therefore, research was needed to evaluate coapplication of $\mathrm{K}$ fertilizers and glyphosate for crop response and weed control compatibility. The objective of this study was to determine the impact of $\mathrm{K}$ fertilizer source and application rate on soybean injury, weed control, tissue nutrient concentration, and grain yield when applied alone and tank-mixed with glyphosate.

\section{Materials and Methods}

Field research was conducted in 2004 and 2005 at multiple Missouri sites. These included the University of Missouri Greenley Center near Novelty $\left(40^{\circ} 01^{\prime} \mathrm{N}, 92^{\circ} 11^{\prime} \mathrm{W}\right)$ on a Putnam silt loam (fine, smectitic, mesic Aeric Vertic Epiaqualfs) with a high soil test $\mathrm{K}$ (380 to $400 \mathrm{~kg} \mathrm{~K} \mathrm{ha}^{-1}$ ) and weed density, the Delta Center Lee Farm near Portageville $\left(36^{\circ} 24^{\prime} \mathrm{N}, 89^{\circ} 42^{\prime} \mathrm{W}\right)$ on a Tiptonville fine sandy loam (finesilty, mixed, superactive, thermic Oxyaquic Argiudolls) in locations with a high (from 390 to $470 \mathrm{~kg} \mathrm{Kha}^{-1}$ ) soil test $\mathrm{K}$ and weed density, and the Delta Center Rice Farm near Malden $\left(36^{\circ} 34^{\prime} \mathrm{N} 89^{\circ} 57^{\prime} \mathrm{W}\right)$ on a Dewitt silt loam (fine, smectitic, thermic Typic Albaqualfs) with medium (290 $\mathrm{kg} \mathrm{K} \mathrm{ha}^{-1}$ ) soil test $\mathrm{K}$ and low weed density [23]. The initial exchangeable $\left(1 \mathrm{M} \mathrm{NH} \mathrm{NH}_{4} \mathrm{AOc}\right)$ soil test $\mathrm{K}$ levels were based on University of Missouri soil test interpretations [23]. Soil test values for individual sites are reported in Table 1. Crop rotations were corn-soybean at Novelty and Portageville and rice-soybean at Malden.

The experiment was arranged as a randomized-complete block design with four replications with experimental plots measuring from 2.3 by $8 \mathrm{~m}$ to 3 by $15.2 \mathrm{~m}$. Precipitation and average monthly air temperatures are reported in Table 2 . At Novelty, “Thompson 3999RR” glyphosate-resistant soybeans were no-till seeded on 21 May 2004 and 29 April 2005 in 38 $\mathrm{cm}$ rows at 494,000 seeds ha ${ }^{-1}$. At Portageville and Malden, "Dyna-Grow 3583 NRR" glyphosate-resistant soybeans were seeded into conventionally tilled soil on 9 June 2004 and 5 June 2005 in $76 \mathrm{~cm}$ rows at 443,000 seeds ha ${ }^{-1}$.

All treatments were applied with a $\mathrm{CO}_{2}$-propelled hand sprayer calibrated to deliver $140 \mathrm{~L} \mathrm{ha}^{-1}$ at Novelty and $187 \mathrm{~L} \mathrm{ha}^{-1}$ at Portageville and Malden. The spray boom was equipped with 8002 flat-fan nozzles (Spray Systems Co., North Avenue, Wheaton, IL) spaced $38 \mathrm{~cm}$ apart and positioned $41 \mathrm{~cm}$ above the canopy. Treatments consisted of four application rates $\left(0,2.2,8.8\right.$, and $\left.17.6 \mathrm{~kg} \mathrm{Kha}^{-1}\right)$ and four sources $\mathrm{K}$ fertilizer. The sources were potassium chloride (0-0-62-0 as \% $\mathrm{N}-\% \mathrm{P}_{2} \mathrm{O}_{5}-\% \mathrm{~K}_{2} \mathrm{O}-\%$ S, PCS, Potash Corp. of Saskatchewan, 1101 Skokie Blvd., Suite 400, Northbrook, IL), K phosphate plus urea (3-18-18-0, NA-CHURS/ALPINE Solutions, 421 Leader Street, Marion, $\mathrm{OH}), \mathrm{K}$ thiosulfate (0-0-25-17, Tessenderlo Kerley, Inc., 2255 N. 44th Street, Suite 300, Phoenix, AZ), K thiosulfate plus urea-triazone (5-0-20-13, Tessenderlo Kerley, Inc., 2255 N. 44th Street, Suite 300, Phoenix, AZ), and diammonium sulfate (DAS) at $3 \mathrm{~kg} \mathrm{ha}^{-1}$. They were applied at the V4-V5 stage of development [21], which was approximately 7 to $10 \mathrm{~d}$ prior to the R1 stage of development. A DAS treatment was included because it is commonly added to glyphosate ( $N$-(phosphonomethyl)glycine) to reduce the antagonistic 
TABle 2: Mean monthly air temperature and precipitation at Novelty, Portageville, and Malden in 2004 and 2005 growing seasons and 10 -year average (2000 to 2009).

\begin{tabular}{|c|c|c|c|c|c|c|c|c|c|c|c|c|c|c|c|c|c|c|}
\hline \multirow{3}{*}{ Month } & \multicolumn{9}{|c|}{ Air temperature } & \multicolumn{9}{|c|}{ Precipitation } \\
\hline & \multicolumn{2}{|c|}{ Novelty } & \multirow{2}{*}{$\begin{array}{c}10-y r \\
\text { average }\end{array}$} & \multicolumn{2}{|c|}{ Portageville } & \multirow{2}{*}{$\begin{array}{c}10-y r \\
\text { average }\end{array}$} & \multicolumn{2}{|c|}{ Malden } & \multirow{2}{*}{$\begin{array}{c}10-y r \\
\text { average }\end{array}$} & \multicolumn{2}{|c|}{ Novelty } & \multirow{2}{*}{$\begin{array}{c}10-y r \\
\text { average }\end{array}$} & \multicolumn{2}{|c|}{ Portageville } & \multirow{2}{*}{$\begin{array}{c}10-y r \\
\text { average }\end{array}$} & \multicolumn{2}{|c|}{ Malden } & \multirow{2}{*}{$\begin{array}{c}10-y r \\
\text { average }\end{array}$} \\
\hline & 2004 & 2005 & & 2004 & $\begin{array}{l}2005 \\
\quad\left({ }^{\circ} \mathrm{C}\right)\end{array}$ & & 2004 & 2005 & & 2004 & 2005 & & 2004 & $\begin{array}{c}2005 \\
(\mathrm{~mm})\end{array}$ & & 2004 & 2005 & \\
\hline April & 12.7 & 13.0 & 12.2 & 15.7 & 15.7 & 16.1 & 15.6 & 15.7 & 16.2 & 78.0 & 68.6 & 99.5 & 128.3 & 106.4 & 96.1 & 138.4 & 104.9 & 101.4 \\
\hline May & 18.7 & 16.7 & 17.2 & 22.4 & 20.7 & 21.0 & 22.5 & 20.7 & 21.0 & 119.9 & 55.9 & 113.0 & 173.8 & 15.2 & 119.4 & 155.5 & 25.7 & 114.6 \\
\hline June & 20.7 & 23.3 & 22.0 & 24.4 & 25.7 & 25.3 & 24.5 & 25.7 & 25.3 & 83.6 & 144.5 & 124.4 & 88.6 & 58.4 & 74.8 & 63.2 & 57.4 & 61.6 \\
\hline July & 22.6 & 25.1 & 24.1 & 25.3 & 26.2 & 26.3 & 25.3 & 26.2 & 26.4 & 67.1 & 56.9 & 93.0 & 151.4 & 113.8 & 97.2 & 158.0 & 112.0 & 116.0 \\
\hline Aug. & 19.9 & 24.0 & 23.3 & 23.2 & 27.0 & 26.0 & 23.2 & 26.9 & 26.1 & 206.0 & 81.5 & 121.7 & 81.4 & 99.6 & 55.3 & 123.7 & 156.2 & 68.7 \\
\hline Sept. & 19.4 & 20.9 & 18.9 & 21.8 & 23.9 & 21.9 & 21.4 & 23.6 & 21.8 & 24.9 & 70.1 & 85.2 & 0.0 & 58.2 & 105.9 & 0.0 & 55.1 & 109.3 \\
\hline Oct. & 12.7 & 12.6 & 12.2 & 17.8 & 16.6 & 16.3 & 17.7 & 16.3 & 16.2 & 165.6 & 85.1 & 83.7 & 140.0 & 0.0 & 96.3 & 103.9 & 1.3 & 88.1 \\
\hline
\end{tabular}

TABLE 3: The effect of fertilizer additive on soybean injury $3 \mathrm{~d}$ after treatment (DAT) in the presence and absence (weed-free) of glyphosate, and total weed dry weight reduction of fertilizer additives tank-mixed with glyphosate at Novelty 28 DAT in 2004 and 2005 . Data were combined over years ${ }^{\mathrm{a}}$.

\begin{tabular}{|c|c|c|c|c|}
\hline \multirow[b]{2}{*}{ Fertilizer additive $^{c}$} & \multirow{2}{*}{$\begin{array}{c}\text { Rate } \\
\left(\mathrm{Kg} \mathrm{Kha}^{-1}\right)\end{array}$} & \multicolumn{2}{|c|}{ Injury 3 DAT } & \multirow{2}{*}{$\begin{array}{c}\text { Total weed }{ }^{\mathrm{b}} \text { dry weight reduction } \\
\text { Glyphosate tank mixture } \\
(\%)\end{array}$} \\
\hline & & Weed-free & $\begin{array}{l}\text { Glyphosate tank mixture } \\
(\%)\end{array}$ & \\
\hline Non-treated & & & 0 & 0 \\
\hline Weed-free & & 0 & $-^{\mathrm{d}}$ & 100 \\
\hline NIS & & - & 1 & 93 \\
\hline NIS + DAS & & - & 1 & 93 \\
\hline \multirow{3}{*}{$0-0-62-0$} & 2.2 & 0 & 1 & 88 \\
\hline & 8.8 & 2 & 3 & 91 \\
\hline & 17.6 & 6 & 6 & 90 \\
\hline \multirow{3}{*}{$3-18-18-0$} & 2.2 & 0 & 0 & 96 \\
\hline & 8.8 & 1 & 3 & 96 \\
\hline & 17.6 & 4 & 3 & 88 \\
\hline \multirow{3}{*}{$0-0-25-17$} & 2.2 & 1 & 1 & 88 \\
\hline & 8.8 & 3 & 5 & 86 \\
\hline & 17.6 & 5 & 6 & 84 \\
\hline \multirow{3}{*}{$5-0-20-13$} & 2.2 & 0 & 1 & 96 \\
\hline & 8.8 & 4 & 6 & 87 \\
\hline & 17.6 & 6 & 6 & 85 \\
\hline $\operatorname{LSD}(P=0.01)$ & & & 2 & 11 \\
\hline
\end{tabular}

${ }^{a}$ Abbreviations: DAS: diammonium sulfate; NIS: non-ionic surfactant.

${ }^{b}$ Weed species included common lambsquarters in 2004, common ragweed in 2005, common waterhemp in 2004 and 2005, and giant foxtail in 2004 and 2005. Total dry weight reduction was calculated as $100(1-($ total weed dry weight/untreated weed dry weight $))$.

${ }^{\mathrm{c}}$ Fertilizer additives included 3-18-18-0 as $\% \mathrm{~N}-\% \mathrm{P}_{2} \mathrm{O}_{5}-\% \mathrm{~K}_{2} \mathrm{O}-\% \mathrm{~S}, \mathrm{~K}$ phosphate + urea (NA-CHURS/ALPINE); 0-0-25-17, $\mathrm{K}$ thiosulfate; 5-0-20-13, $\mathrm{K}$ thiosulfate + urea-triazone (Trisert-K+, Tessenderlo Kerley); and 0-0-62-0, potassium chloride. All fertilizer additives with glyphosate included non-ionic surfactant.

${ }^{\mathrm{d}}$ Treatment was not included.

effects of hard water on weed control $[4,6]$. All glyphosate treatments included nonionic surfactant (Activator-90, a mixture of alkyl polyoxyethylene ethers and free fatty acids, Loveland Industries Inc., P.O. Box 1289, Greeley, CO) at $0.25 \% \mathrm{v} / \mathrm{v}$ at Novelty and $0.5 \% \mathrm{v} / \mathrm{v}$ at Portageville and Malden. Foliar fertilizer treatments were applied in the absence of glyphosate to plots that were maintained weedfree or sprayed as a mixture with glyphosate (formulated as Roundup Original, Monsanto Co., St. Louis, MO) at $0.84 \mathrm{~kg} \mathrm{aeha}^{-1}$ to plots with weeds at all locations. At
Portageville and Malden, a two-pass weed management program included a blanket application of glyphosate followed by the foliar additives alone or tank-mixed with glyphosate. Weed species at Novelty (Table 3 ) and Portageville (Table 4) were 15 to $30 \mathrm{~cm}$ tall with densities from 40 to $200 \mathrm{~m}^{-2}$ at the time of application. Because weeds were nearly nonexistent at the Malden site, with densities less than one weed $\mathrm{m}^{-2}$, weed control was not evaluated at this site.

Foliar salt injury was rated on a scale of 0 (no effect) to $100 \%$ (complete crop or weed death). Injury was rated 3, 7, 
TABLE 4: Soybean injury and weed control from fertilizer additives applied alone in a weed-free plot and tank-mixed with glyphosate plus non-ionic surfactant 14 days after treatment (DAT) at Portageville in 2004 and 2005 in weedy plots. Palmer amaranth, ivyleaf morning glory, and large crabgrass control of fertilizer additives plus glyphosate and nonionic surfactant 21 DAT at Portageville ${ }^{\mathrm{a}}$. Data were combined over years.

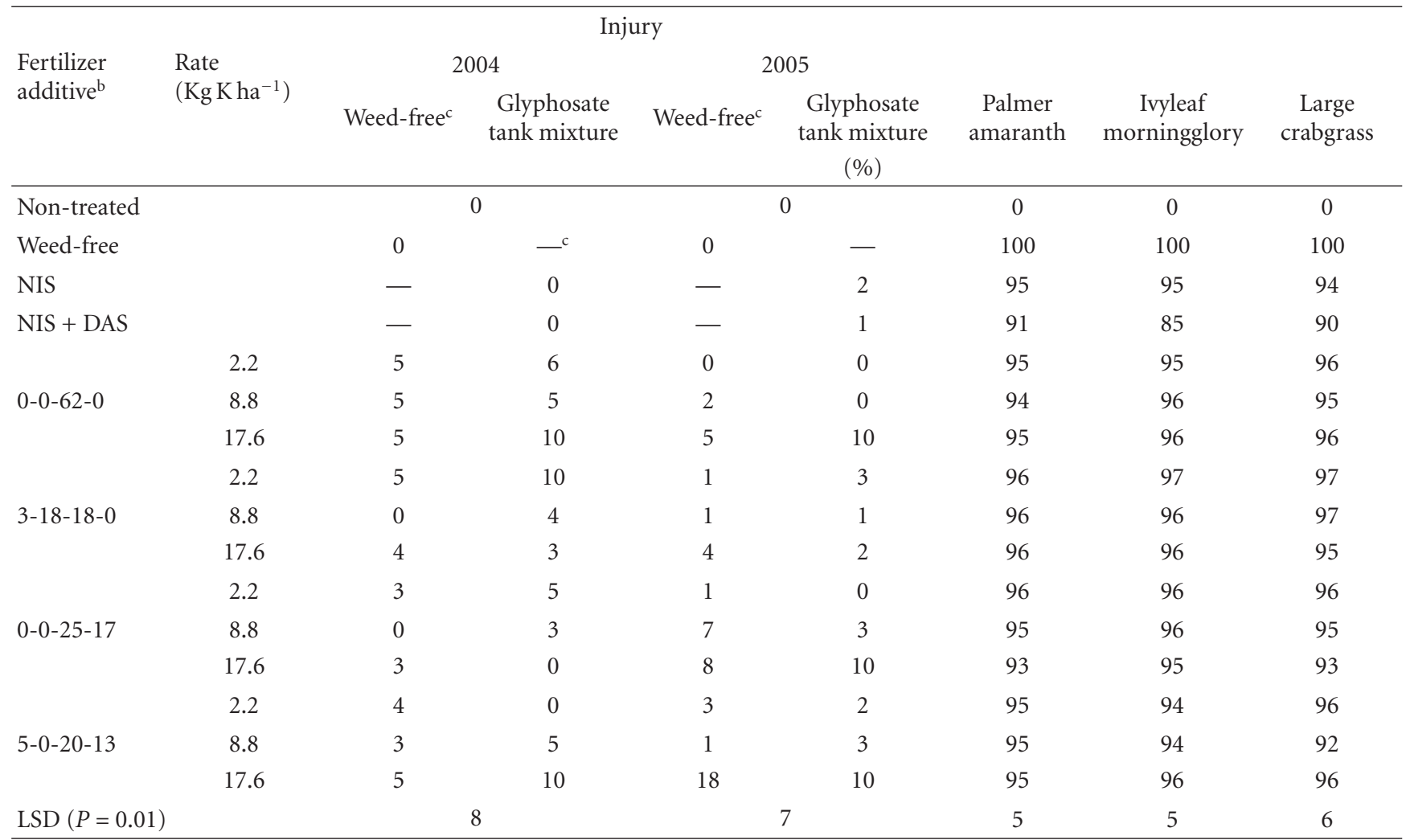

${ }^{a}$ Abbreviations: DAS, diammonium sulfate; DAT, days after treatment; KTS, potassium thiosulfate; NIS, non-ionic surfactant.

${ }^{\mathrm{b}}$ Fertilizer additives included 3-18-18, K phosphate + urea (NA-CHURS/ALPINE); 0-0-25-17, K thiosulfate; 5-0-20-13, K thiosulfate + urea-triazone (Trisert$\mathrm{K}$, Tessenderlo Kerley); and 0-0-62, potassium chloride. All tank mixtures with glyphosate included non-ionic surfactant.

${ }^{\mathrm{c}}$ Treatment was not included.

and 14 days after treatment (DAT) at Novelty; and 14 and 21 DAT at Portageville. Samples of trifoliolate leaves consisting of 20 uppermost, fully expanded leaves were randomly collected at initial bloom (14 DAT) from each plot at Novelty and Malden [22]. Leaves were dried at 60 to $70^{\circ} \mathrm{C}$ for $48 \mathrm{~h}$ in a forced air oven, weighed, and ground in a Wiley Mill (Swedesboro, NJ) to pass through a $1 \mathrm{~mm}$-sieve. Leaf samples were digested for $\mathrm{N}, \mathrm{P}, \mathrm{K}, \mathrm{Ca}, \mathrm{Mg}, \mathrm{Mn}, \mathrm{Fe}, \mathrm{Cu}$, and $\mathrm{Zn}$ using a modified wet acid dilution procedure [24]. The leaf samples were dried at $100^{\circ} \mathrm{C}$, ground, and digested with a Hach Digesdahl (Hach Company, Loveland, $\mathrm{CO}$ ) using $\mathrm{H}_{2} \mathrm{SO}_{4}$ and $\mathrm{H}_{2} \mathrm{O}_{2}$. Tissue concentrations of $\mathrm{K}, \mathrm{Ca}, \mathrm{Mg}, \mathrm{Mn}, \mathrm{Fe}, \mathrm{Cu}$, and $\mathrm{Zn}$ were determined using an atomic absorption spectrophotometer (Perkin-Elmer, Wellesley, MA) [24]. Phosphorus was determined colormetrically $[25,26]$ with a spectrophotometer (Genesys 10, Thermo Spectronic, Rochester, NY). Sulfur and B were determined on dry-ashed samples taken up in $0.1 \mathrm{M} \mathrm{HCl}$ using ICP spectroscopy.

A biomass harvest of individual weeds from two 38- by $76-\mathrm{cm}$ quadrats was collected 28 DAT to determine weed control at Novelty. Percent dry weight reduction was calculated as $100 *[1-$ (total weed dry weight/nontreated weed dry weight)]. At Portageville, weed control for individual weed species was visually evaluated 21 DAT on a scale of 0 (no effect) to $100 \%$ (complete plant death). The Malden site had been in rice production, and weeds were nearly nonexistent, so weed control was not evaluated or reported in 2004 or 2005. Grain was harvested with a small plot combine (Kincaid Equipment Manufacturing, P.O. Box 400, Haven, KS 47543) and moisture adjusted to $130 \mathrm{~g} \mathrm{~kg}^{-1}$ before analysis. Grain samples were collected from the Novelty and Malden sites and analyzed for protein and oil concentration with near-infrared spectroscopy (Foss Infratec 1241 Grain Analyzer, 8091 Wallace Rd., Eden Prairie, MN).

An analysis of variance was conducted using PROC GLM [27] and subjected to an F Max test for homogeneity [28]. Data were combined over years and locations when variances were homogenous or when interactions were not observed. Visual injury and weed control data were transformed to the arc sine before ANOVA. Because this transformation did not affect conclusions, original means were reported. Individual treatment differences were determined using Fisher's Protected LSD at $P=0.01$. Quadratic regression analysis was performed using best-fit analysis determined with SigmaPlot (Vers. 8.02, SPSS Inc., Chicago, IL). Significance was determined using PROC REG [27]. 


\section{Results and Discussion}

3.1. Soybean Injury and Weed Control. Soybean injury was primarily necrosis of leaves exposed to the foliar applications of fertilizer additives (visual observation). Glyphosate alone caused minimal $(<2 \%)$ foliar injury (Tables 3 and 4 ). Glyphosate may cause injury to glyphosate-resistant soybean in some instances and formulations, but injury is usually minimal, short, and the plant outgrows these effects [29, 30]. At Novelty 3 DAT, injury from foliar fertilizers applied alone or in tank-mixture with glyphosate was less than $6 \%$ (Table 3). All plants with leaf injury recovered and had no visual symptoms 14 DAT (data not presented). This was similar to other research evaluating higher rates (from 17.5 to $43 \mathrm{~kg} \mathrm{ha}^{-1}$ ) of these products [20]. All treatments except 5-0-20-13 at $17.6 \mathrm{~kg} \mathrm{ha}^{-1}$ applied alone in 2005 injured soybean less than $10 \% 14$ DAT at Portageville (Table 4), with nearly complete recovery ( $<5 \%$ injury) 21 DAT (data not presented). At both locations, injury generally increased as the fertilizer rate increased in the presence or absence of glyphosate. High rates $\left(17.6 \mathrm{~kg} \mathrm{ha}^{-1}\right)$ of $0-0-62-0$ in 2004 and 2005, 0-0-25-17 in 2005, and 5-0-20-13 in 2004 and 2005 injured soybean from 8 to $10 \%$ greater than DAS. This may be due to a higher salt index of $0-0-62-0(\mathrm{KCl})[31]$. Foliar fertilization in soybean may cause leaf damage that subsequently reduces grain yield in some instances $[17,20$, 32, 33].

Glyphosate plus 0-0-62 at 8.8 and $17.6 \mathrm{~kg} \mathrm{ha}^{-1}, 3-18-18-0$ at 2.2 and $8.8 \mathrm{~kg} \mathrm{ha}^{-1}$, and 5-0-20-13 at $2.2 \mathrm{~kg} \mathrm{ha}^{-1}$ controlled weeds greater than $90 \%$ at Novelty 28 DAT (Table 3). At Portageville 21 DAT, all treatments except glyphosate plus DAS controlled Palmer amaranth, morningglory spp., and large crabgrass greater than $90 \%$ (Table 4 ). The K-fertilizer additives controlled weeds greater than or equal to DAS at Novelty and Portageville.

3.2. Leaf Nutrient Concentration. Leaf samples were collected from the Novelty and Malden locations. Because no interactions appeared between the Novelty and Malden locations for 2004 and 2005, data were combined over the four site-years. There was no effect of fertilizer source in the presence or absence of glyphosate on $\mathrm{Ca}(P=0.56)$, Fe $(P=0.40), \operatorname{Mg}(P=0.08), \operatorname{Mn}(P=0.72), \mathrm{P}(P=$ $0.24)$, or $\mathrm{Zn}(P=0.27)$ concentrations in soybean leaves 14 DAT (data not presented). However, differences in leaf tissue $\mathrm{K}(P=0.03), \mathrm{S}(P=0.03), \mathrm{B}(P=0.0001)$, and $\mathrm{Cu}(P=0.008)$ concentrations among treatments were detected. Soil test $\mathrm{K}$ levels were medium at Malden $\left(290 \mathrm{~kg} \mathrm{ha}^{-1}\right)$ and high at Novelty $\left(390 \mathrm{~kg} \mathrm{ha}^{-1}\right)$. However, leaf $\mathrm{K}$ concentration was sufficient, averaging $17.2 \mathrm{~g} \mathrm{~kg}^{-1}$ at Malden and $26.8 \mathrm{~g} \mathrm{~kg}^{-1}$ at Novelty [24]. Similarly, average S and $\mathrm{B}$ leaf tissue concentrations were in the sufficient range, but $\mathrm{Cu}$ was slightly below the sufficiency range of 10 to $30 \mathrm{mg} \mathrm{kg}^{-1}$.

Leaf $\mathrm{K}$ concentration increased $9 \%$ when $5-0-20-13$ was applied alone when compared to the nontreated control (Table 5). All rates of 5-0-20-13 in the absence of glyphosate increased leaf tissue $\mathrm{K}$ concentration from 8 to $10 \%$ when compared to DAS. Similar increases in leaf tissue K concentration were observed when $\mathrm{K}_{2} \mathrm{SO}_{4}$ was applied alone [22]. Fertilizers with varying N-P-K ratios seldom increased tissue N-P-K concentration at R2 for soils that tested at or above optimum soil $\mathrm{P}$ and $\mathrm{K}$ levels for soybean [15]. Tank mixtures of glyphosate with $0-0-25-17$ at $2.2 \mathrm{~g} \mathrm{~kg}^{-1}$ or $5-0-$ $20-13$ at $8.8 \mathrm{~g} \mathrm{~kg}^{-1}$ reduced leaf $\mathrm{K}$ concentration from 8 to $9 \%$ when compared to the fertilizer additives applied alone. This might stem from a reduction in $\mathrm{K}$ uptake caused by the presence of weeds, as indicated by leaf $\mathrm{K}$ concentrations that were similar to the nontreated control and glyphosate tank-mixture treatments. However, increased $\mathrm{K}$ nutrient uptake and yields were observed when weeds competed throughout the growing season in snap bean (Phaseolus vulgaris) [34]. Soybean aphids (Aphis glycines Matsumura) were not observed in this research. However, fields with low soil and tissue test $\mathrm{K}$ show increased-abundance and rates of aphid population increase compared to medium and high soil test $\mathrm{K}$ treatments, a situation that farmers might need to manage [35]. In this research, soils with low test $\mathrm{K}$ levels also had low leaf tissue $\mathrm{K}, \mathrm{Ca}, \mathrm{B}, \mathrm{Mn}$, and Fe concentrations [35].

Leaf $S$ concentration was lowest $\left(2.6 \mathrm{~g} \mathrm{~kg}^{-1}\right)$ in the nontreated control. Leaf $S$ concentration significantly increased with all fertilizer additives except $0-0-62-0$ at $17.6 \mathrm{~g} \mathrm{~kg}^{-1}$ when applied alone or when 3-18-18-0 was applied at 2.2 or $8.8 \mathrm{~g} \mathrm{~kg}^{-1}$ with glyphosate. Higher leaf $\mathrm{S}$ concentrations were observed with fertilizer additives that did not include an $S$ source. Thus, higher leaf $S$ concentrations probably resulted from increased soil uptake caused by the fertilizer additive in a weed-free environment.

The highest leaf B concentration $\left(42.0 \mathrm{mg} \mathrm{kg}^{-1}\right)$ was in the nontreated control, which was similar to the weed-free control. Leaf tissue $\mathrm{B}$ concentration decreased when high rates $\left(17.6 \mathrm{~g} \mathrm{~kg}^{-1}\right)$ of $0-0-62-0,3-18-18-0$, and $0-0-25-18$, or when a low rate $\left(2.2 \mathrm{~g} \mathrm{~kg}^{-1}\right)$ of $5-0-20-13$ was applied to weed-free plants or combined with glyphosate. All fertilizer additives except 3-18-18-0 at 2.2 or $8.8 \mathrm{~g} \mathrm{~kg}^{-1}$ combined with glyphosate reduced leaf $\mathrm{B}$ concentration when compared to the nontreated control. Glyphosate plus $0-0-62-0$ at $17.6 \mathrm{~g} \mathrm{~kg}^{-1}$ reduced B concentration when compared to DAS.

Copper concentration in soybean leaves was $1.2 \mathrm{~g} \mathrm{~kg}^{-1}$ greater in the weed-free when compared to the nontreated control. All fertilizer additive combinations with glyphosate had $\mathrm{Cu}$ concentrations similar to DAS. An application of 0-0-25-17 at $2.2 \mathrm{~g} \mathrm{~kg}^{-1}$ increased $\mathrm{Cu}$ concentration from 1.2 to $1.4 \mathrm{~g} \mathrm{~kg}^{-1}$ compared to the nontreated control or when combined with glyphosate. Leaf concentrations of Ca, $\mathrm{Mg}$, and $\mathrm{Mn}$ decreased in nonglyphosate-resistant soybean while $\mathrm{P}$ and $\mathrm{Cu}$ concentrations increase [36], but no known interaction between weeds or macro- and micronutrient tissue concentrations have been reported. Factors affecting leaf tissue nutrient concentrations 14 DAT included weed interference, fertilizer additive source, and additive rates.

Compared to the nontreated control, grain oil concentration for all fertilizer additive treatments was 7 to $10 \mathrm{~g} \mathrm{~kg}^{-1}$ higher, and protein concentration was 9 to $16.1 \mathrm{~g} \mathrm{~kg}^{-1}$ lower $(P=0.0001$, data not presented). However, fertilizer additives had similar oil and protein concentrations when applied alone or tank-mixed with glyphosate (data not presented). In other research, physical injury to plants and 
Table 5: Soybean leaf tissue K, S, B, and Cu concentrations 14 days after treatment at Novelty and Malden in 2004 and 2005. Data were combined over site-years.

\begin{tabular}{|c|c|c|c|c|c|c|c|c|c|}
\hline \multirow{2}{*}{$\begin{array}{l}\text { Fertilizer } \\
\text { additive }^{\mathrm{a}}\end{array}$} & \multirow{2}{*}{$\begin{array}{l}\text { Rate } \\
\left(\mathrm{Kg} \mathrm{Kha}^{-1}\right)\end{array}$} & \multicolumn{2}{|c|}{$\mathrm{K}$} & \multicolumn{2}{|r|}{$\mathrm{S}$} & \multicolumn{2}{|r|}{$\mathrm{B}$} & \multicolumn{2}{|c|}{$\mathrm{Cu}$} \\
\hline & & Weed-free & $\begin{array}{r}\text { Glyphosate } \\
\text { tank mixture } \\
\left(\mathrm{g} \mathrm{kg}^{-1}\right.\end{array}$ & $\begin{array}{l}\text { Weed- } \\
\text { free }\end{array}$ & $\begin{array}{l}\text { Glyphosate } \\
\text { tank mixture }\end{array}$ & $\begin{array}{l}\text { Weed- } \\
\text { free }\end{array}$ & $\begin{array}{c}\text { Glyphosate } \\
\text { tank mixture } \\
(\mathrm{n}\end{array}$ & $\begin{array}{l}\text { Weed-free } \\
\left.\mathrm{kg}^{-1}\right)\end{array}$ & $\begin{array}{l}\text { Glyphosate } \\
\text { tank mixture }\end{array}$ \\
\hline Non-treated & & \multicolumn{2}{|c|}{21.4} & \multicolumn{2}{|r|}{2.6} & \multicolumn{2}{|r|}{42.0} & \multicolumn{2}{|c|}{9.2} \\
\hline Weed-free & & 22.4 & $-^{\mathrm{b}}$ & 2.7 & - & 39.2 & - & 10.4 & - \\
\hline $\mathrm{NIS}^{\mathrm{c}}$ & & - & 22.3 & - & 2.7 & - & 39.8 & - & 9.3 \\
\hline NIS + DAS & & - & 21.2 & - & 2.7 & - & 39.5 & - & 9.1 \\
\hline \multirow{3}{*}{$0-0-62-0$} & 2.2 & 21.6 & 21.7 & 2.8 & 2.7 & 40.5 & 38.0 & 9.8 & 9.1 \\
\hline & 8.8 & 21.3 & 21.5 & 2.8 & 2.7 & 37.7 & 36.4 & 10.1 & 9.4 \\
\hline & 17.6 & 22.9 & 21.9 & 2.7 & 2.7 & 37.0 & 35.6 & 10.1 & 9.4 \\
\hline \multirow{3}{*}{$3-18-18-0$} & 2.2 & 22.7 & 22.7 & 2.8 & 2.8 & 41.4 & 39.9 & 9.9 & 9.6 \\
\hline & 8.8 & 22.1 & 21.8 & 2.8 & 2.8 & 39.6 & 40.1 & 9.7 & 9.5 \\
\hline & 17.6 & 22.7 & 21.6 & 2.8 & 2.7 & 38.1 & 37.4 & 9.7 & 9.3 \\
\hline \multirow{3}{*}{$0-0-25-17$} & 2.2 & 22.5 & 20.6 & 2.8 & 2.7 & 38.9 & 37.3 & 10.4 & 9.0 \\
\hline & 8.8 & 22.0 & 21.7 & 2.8 & 2.7 & 38.8 & 35.7 & 10.0 & 9.6 \\
\hline & 17.6 & 22.0 & 22.9 & 2.8 & 2.7 & 37.5 & 36.9 & 10.0 & 9.4 \\
\hline \multirow{3}{*}{$5-0-20-13$} & 2.2 & 23.0 & 22.7 & 2.8 & 2.7 & 37.4 & 37.2 & 9.9 & 9.4 \\
\hline & 8.8 & 23.5 & 21.3 & 2.8 & 2.7 & 38.7 & 36.5 & 10.0 & 9.3 \\
\hline & 17.6 & 23.0 & 21.5 & 2.8 & 2.7 & 39.3 & 36.2 & 10.1 & 9.4 \\
\hline $\operatorname{LSD}(P=0.01)$ & & \multicolumn{2}{|c|}{1.8} & \multicolumn{2}{|r|}{0.2} & \multicolumn{2}{|r|}{3.8} & \multicolumn{2}{|c|}{1.1} \\
\hline
\end{tabular}

${ }^{a}$ Fertilizer additives included 3-18-18-0 (N-P-K-S), K phosphate + urea (NA-CHURS/ALPINE); 0-0-25-17, K thiosulfate; 5-0-20-13, K thiosulfate + ureatriazone (Trisert-K, Tessenderlo Kerley); and 0-0-62-0, potassium chloride. All tank mixtures with glyphosate included non-ionic surfactant.

${ }^{\mathrm{b}}$ Treatment was not included.

${ }^{\mathrm{c}}$ Abbreviations: DAS: diammonium sulfate; NIS: non-ionic surfactant.

stand loss affected grain oil composition [37], but in this research effective weed control was essential for maintaining high grain oil concentrations regardless of the fertilizer additive. When applied at high rates, glyphosate affected nitrogen assimilation in glyphosate-resistant soybean, which subsequently reduced total oil concentration [38]; however, no effect on leaf $\mathrm{N}$ concentration was observed in this study.

3.3. Grain Yield. Grain yields for the weed-free control were ranked Novelty in 2004, $\left(4460 \mathrm{~kg} \mathrm{ha}^{-1}\right)$, Malden in 2004 and $2005\left(3360 \mathrm{~kg} \mathrm{ha}^{-1}\right)$, Novelty in $2005\left(3200 \mathrm{~kg} \mathrm{ha}^{-1}\right)$, and Portageville in 2004 and $2005\left(2640 \mathrm{~kg} \mathrm{ha}^{-1}\right)$. In general, grain yields were 1200 to $1400 \mathrm{~kg} \mathrm{ha}^{-1}$ greater at Novelty in 2004 (high yield environment) (Figures 1(a) and 1(b)) than in 2005 (low yield environment) (Figures 2(a) and 2(b)). This was due to $135 \mathrm{~mm}$-greater-precipitation in July and August (Table 2), which probably caused a significant yearby-treatment interaction. The growing environment, including row spacing, latitude, weed species and density, cultivar, temperature, and rainfall (Table 2), differed between Novelty and Portageville, which caused an interaction between these two sites with high weed populations. In general, the $\mathrm{K}$ additive treatments at Portageville (Figures 3(a) and 3(b)) had grain yields similar to Novelty in 2005 (Figures 2(a) and 2(b)). But differing weed control programs—one pass at
Novelty, two passes at Portageville-resulted in varied grain yield responses when $\mathrm{K}$ additives were applied to the weedfree control treatments compared to tank mixtures with glyphosate. In July and August, rainfall at Portageville and Malden was more consistent than at Novelty, which allowed data to be combined over years at the individual locations. The Malden site had a low soil test $\mathrm{K}\left(37 \mathrm{mg} \mathrm{K} \mathrm{kg}^{-1}\right)$ with average leaf $\mathrm{K}$ concentration of $17.2 \mathrm{~g} \mathrm{~kg}^{-1}$. This is below the critical leaf $\mathrm{K}$ concentration $\left(24.3 \mathrm{~g} \mathrm{~kg}^{-1}\right)$ at R1 for optimal yield [39]. The low soil test $\mathrm{K}$ probably limited yield potential at this location.

Grain yield increased when fertilizer additives were applied to weed-free soybean at $8.8 \mathrm{~kg} \mathrm{Kha}^{-1}$ at Novelty in 2004 (Figure 1(a)), but in 2005 there was no grain yield response (Figure 2(a)). In 2004 and 2005, there was no yield increase with fertilizer additives combined with glyphosate compared to glyphosate plus DAS (Figures 1(b) and 2(b)). Glyphosate plus $0-0-62-0$ at $17.6 \mathrm{~kg} \mathrm{ha}^{-1}$ reduced grain yield 390 and $360 \mathrm{~kg} \mathrm{ha}^{-1}$ when compared to glyphosate plus DAS and 0-0-62-0 at $17.6 \mathrm{~kg} \mathrm{ha}^{-1}$ applied in the weedfree check (Figure 1(b)). In 2005, K-fertilizer additives applied alone to weed-free checks (Figure 2(a)) resulted in grain yields that were 340 to $940 \mathrm{~kg} \mathrm{ha}^{-1}$ greater than a single application of glyphosate plus the fertilizer additive (Figure 2(b)). The effect was primarily due to the impact of early weed competition on grain yields during a drier 


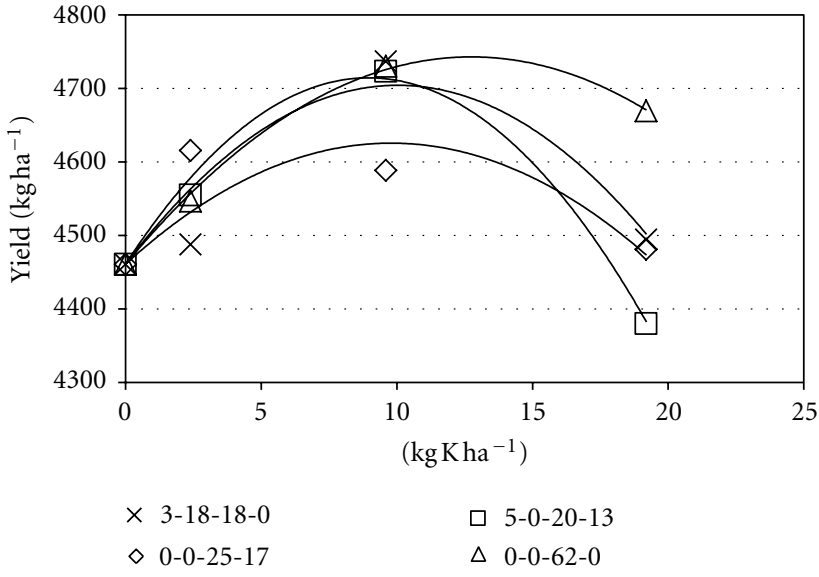

(a)

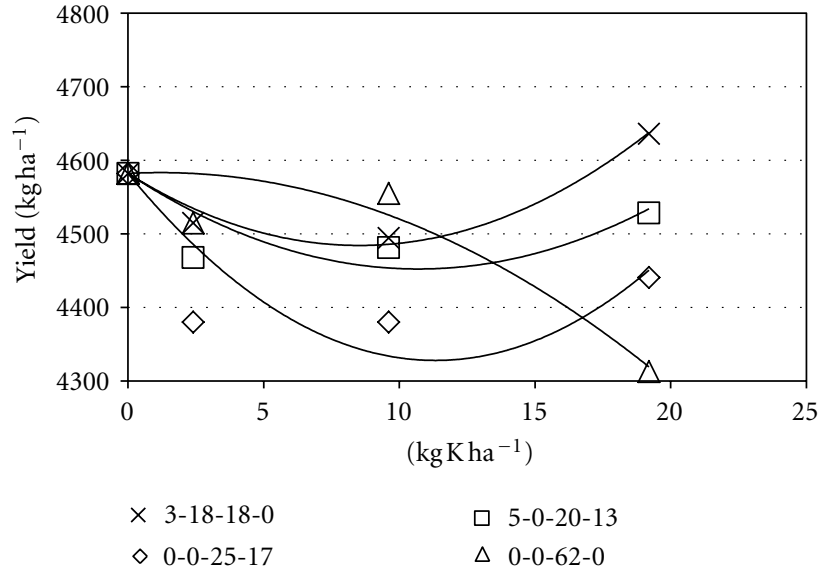

(b)

Figure 1: Soybean grain yield response to K-fertilizer additives $\left(\% \mathrm{~N}-\% \mathrm{P}_{2} \mathrm{O}_{5}-\% \mathrm{~K}_{2} \mathrm{O}-\% \mathrm{~S}\right)$ of $3-18-18-0\left(y=6.1901 x^{2}+48.436 x+4461\right.$, $\left.R^{2}=0.86\right), 0-0-25-17\left(y=-11.258 x^{2}+33.608 x+4461, R^{2}=0.53\right), 5-0-20-13\left(y=-0.4796 x^{2}+56.587 x+4461, R^{2}=0.98\right)$, or $0-0-62-0$ $\left(y=-24.869 x^{2}+44.214 x+4461, R^{2}=0.99\right)$ applied alone to weed-free plots (a) and with glyphosate to weedy plots (b) for 3-18-18-0 $\left(y=3.622 x^{2}-22.952 x+4582, R^{2}=0.96\right), 0-0-25-17\left(y=14.005 x^{2}-44.846 x+4582, R^{2}=0.51\right), 5-0-20-13\left(y=8.2735 x^{2}-24.254 x+4582\right.$, $\left.R^{2}=0.41\right)$, and $0-0-62-0\left(y=6.8447 x^{2}+1.9417 x+4582, R^{2}=0.88\right)$ at Novelty in 2004 . The nontreated, weed-free, and glyphosate plus nonionic surfactant plus diammonium sulfate grain yields were 650,4460 , and $4700 \mathrm{~kg} \mathrm{ha}^{-1}$, respectively. Comparisons between figures are valid. The $\operatorname{LSD}(P=0.01)$ was $330 \mathrm{~kg} \mathrm{ha}^{-1}$.

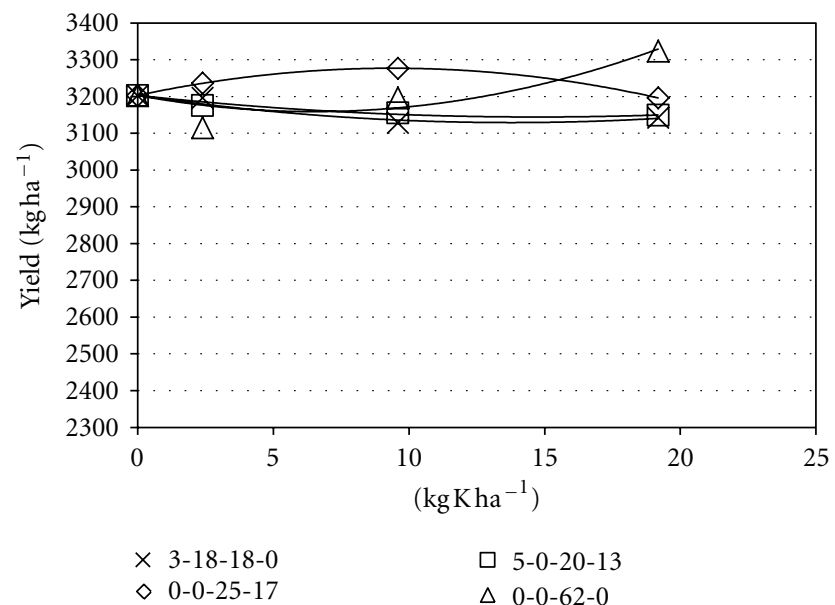

(a)

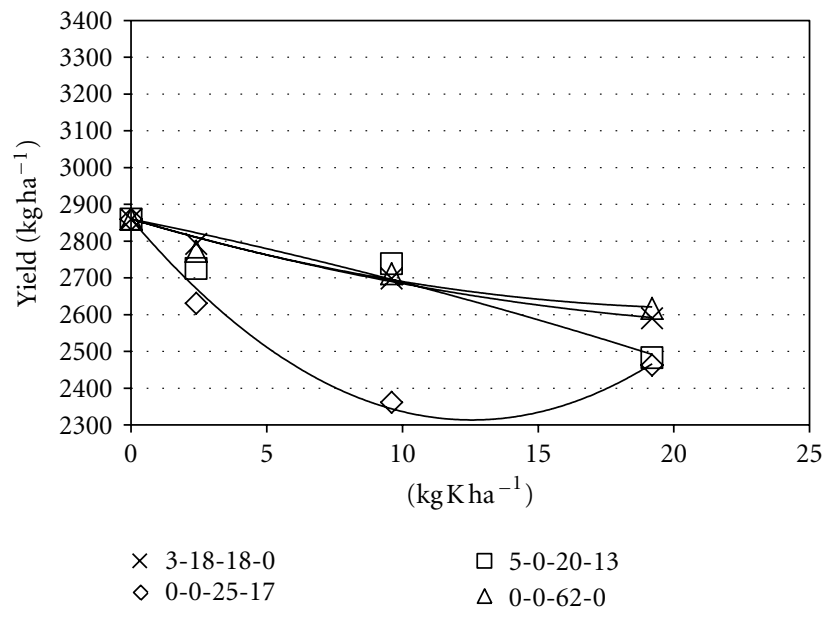

(b)

Figure 2: Soybean grain yield response to K-fertilizer additives $\left(\% \mathrm{~N}-\mathrm{OP}_{2} \mathrm{O}_{5}-\% \mathrm{~K}_{2} \mathrm{O}-\% \mathrm{~S}\right)$ of 3-18-18-0 $\left(y=-1.4832 x^{2}-10.738 x+3203\right.$, $\left.R^{2}=0.92\right), 0-0-25-17\left(y=-0.8783 x^{2}+15.749 x+3203, R^{2}=0.99\right), 5-0-20-13\left(y=1.3693 x^{2}-7.9878 x+3203, R^{2}=0.94\right)$, or $0-0-62-$ $0\left(y=8.0129 x^{2}-13.635 x+3203, R^{2}=0.80\right)$ applied alone to weed-free plots (a) and with glyphosate to weedy plots (b) for 3-18-18-0 $\left(y=2.4953 x^{2}-21.474 x+2860, R^{2}=0.99\right), 0-0-25-17\left(y=8.0594 x^{2}-87.005 x+2860, R^{2}=0.98\right), 5-0-20-13\left(y=10.901 x^{2}-15.061 x+2860\right.$, $\left.R^{2}=0.85\right)$, and $0-0-62-0\left(y=4.8315 x^{2}-21.957 x+2860, R^{2}=0.94\right)$ at Novelty in 2005 . The nontreated, weed-free, and glyphosate plus nonionic surfactant plus diammonium sulfate grain yields were 1070, 3200, and $2750 \mathrm{~kg} \mathrm{ha}^{-1}$, respectively. Comparisons between figures are valid. The $\operatorname{LSD}(P=0.01)$ was $320 \mathrm{~kg} \mathrm{ha}^{-1}$.

year (Table 2). This is one limitation of single-pass weed management, especially during years with low rainfall during seed development. A pre-emergence herbicide followed by postemergence glyphosate could be useful in dry years regardless of fertilizer additive. As the rate of K-fertilizer additives increased when tank-mixed with glyphosate, soybean grain yields decreased (Figure 2(b)). Soybean grain yield was reduced $400 \mathrm{~kg} \mathrm{ha}^{-1}$ when glyphosate was tank-mixed with 5-0-20-13 at $17.6 \mathrm{~kg} \mathrm{ha}^{-1}$ when compared to glyphosate plus NIS, while $0-0-25-17$ at 8.8 and $17.6 \mathrm{~kg} \mathrm{ha}^{-1}$ reduced grain yields 470 and $400 \mathrm{~kg} \mathrm{ha}^{-1}$, respectively.

At Portageville, the weed-free treatments (Figure 3(a)) had grain yields similar to the fertilizer additives with glyphosate (Figure 3(b)), with glyphosate plus 0-0-62-0 at $8.8 \mathrm{~kg} \mathrm{ha}^{-1}$ yielding the most (Figure $3(\mathrm{~b})$ ). All $\mathrm{K}$ additive 


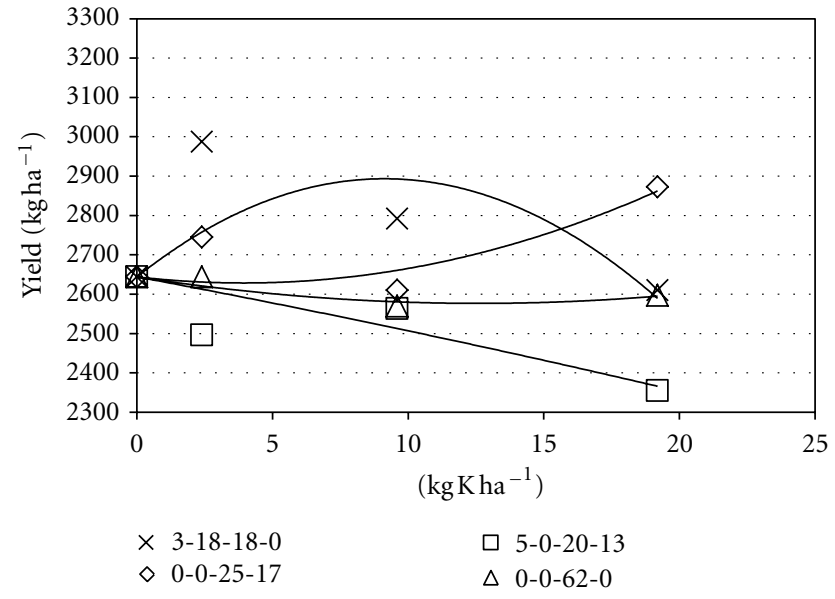

(a)

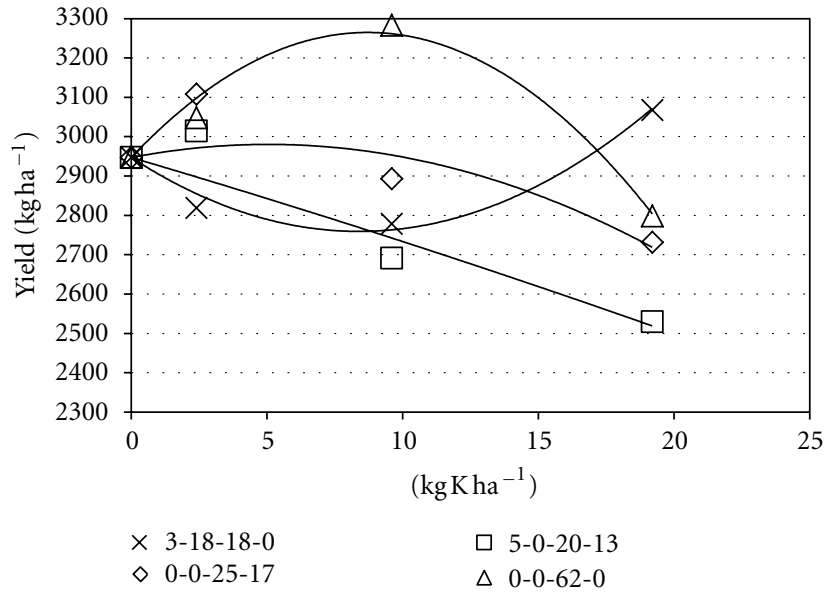

(b)

Figure 3: Soybean grain yield response to K-fertilizer additives ( $\left.\% \mathrm{~N}-\mathrm{OP}_{2} \mathrm{O}_{5}-\% \mathrm{~K}_{2} \mathrm{O}-\% \mathrm{~S}\right)$ of $3-18-18-0\left(y=-29.108 x^{2}+54.656 x+2644\right.$, $\left.R^{2}=0.29\right), 0-0-25-17\left(y=-12.009 x^{2}-7.91 x+2644, R^{2}=0.62\right), 5-0-20-13\left(y=13.163 x^{2}-12.895 x+2644, R^{2}=0.64\right)$, or $0-0-62-0$ $\left(y=-2.2418 x^{2}-10.684 x+2644, R^{2}=0.84\right)$ applied alone to weed-free plots (a) and with glyphosate to weedy plots (b) for 3-18-18-0 $\left(y=6.7384 x^{2}-44.786 x+2947, R^{2}=0.97\right), 0-0-25-17\left(y=-16.937 x^{2}+13.186 x+2947, R^{2}=0.6\right), 5-0-20-13\left(y=-13.38 x^{2}-20.337 x+2947\right.$, $\left.R^{2}=0.89\right)$, and $0-0-62-0\left(y=1.5132 x^{2}+72.982 x+2947, R^{2}=0.98\right)$ at Portageville in 2004 and 2005. Data were combined over years, and comparisons between figures are valid. The nontreated, weed-free, and glyphosate plus nonionic surfactant plus diammonium sulfate grain yields were 1160,2640 , and $2120 \mathrm{~kg} \mathrm{ha}^{-1}$, respectively. The LSD $(P \leq 0.01)$ was $670 \mathrm{~kg} \mathrm{ha}^{-1}$.

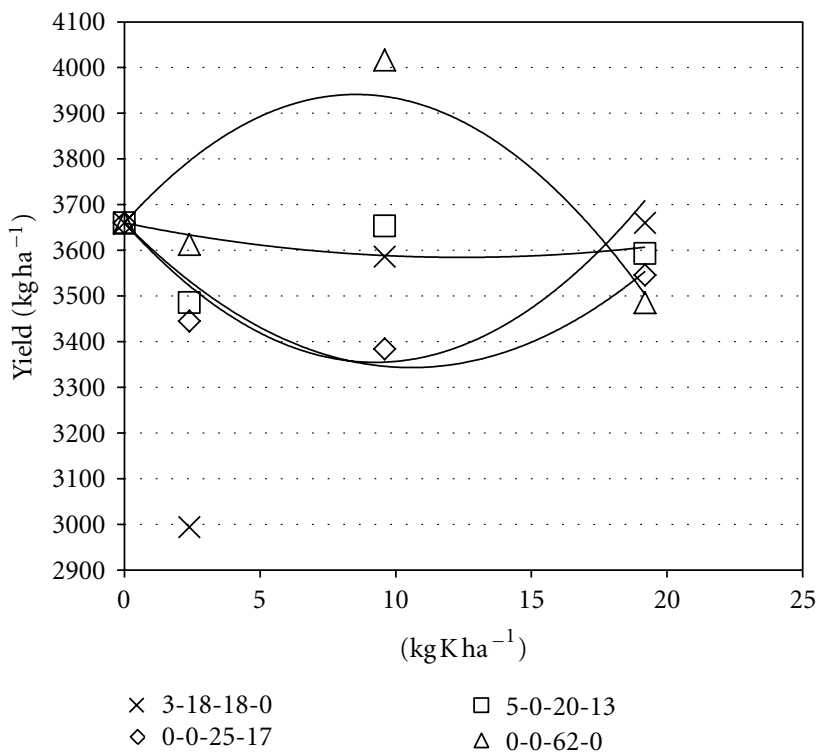

(a)

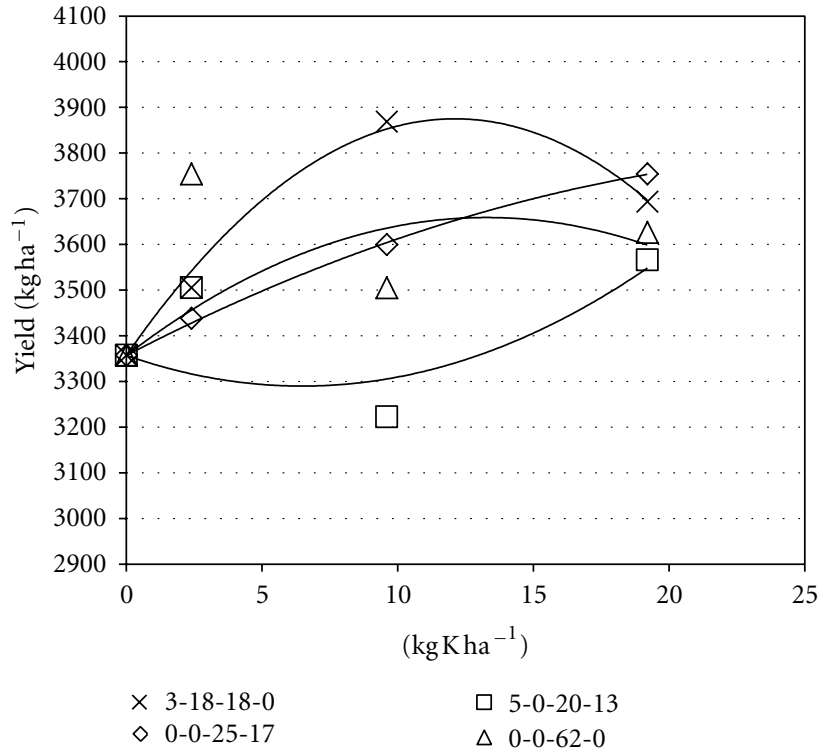

(b)

Figure 4: Soybean grain yield response to K-fertilizer additives $\left(\% \mathrm{~N}-\% \mathrm{P}_{2} \mathrm{O}_{5}-\% \mathrm{~K}_{2} \mathrm{O}-\% \mathrm{~S}\right)$ of 3-18-18-0 $\left(y=63.659 x^{2}-66.085 x+3660\right.$, $\left.R^{2}=-0.07\right), 0-0-25-17\left(y=12.81 x^{2}-59.903 x+3660, R^{2}=0.79\right), 5-0-20-13\left(y=17.383 x^{2}-12.125 x+3660, R^{2}=-0.34\right)$, or $0-0-62-$ $0\left(y=16.945 x^{2}+65.878 x+3660, R^{2}=0.74\right)$ applied alone to weed-free plots (a) and with glyphosate to weedy plots (b) for 3-18-18-0 $\left(y=0.628 x^{2}+85.563 x+3357, R^{2}=0.99\right), 0-0-25-17\left(y=-1.6925 x^{2}+30.832 x+3357, R^{2}=0.99\right), 5-0-20-13\left(y=-19.902 x^{2}-20.694 x+3357\right.$, $\left.R^{2}=0.40\right)$, and $0-0-62-0\left(y=-35.635 x^{2}+45.506 x+3357, R^{2}=-0.24\right)$ at Malden in 2004 and 2005. Data were combined over years, and comparisons between figures are valid. The nontreated, weed-free, and glyphosate plus nonionic surfactant plus diammonium sulfate grain yields were 3230,3660 , and $3570 \mathrm{~kg} \mathrm{ha}^{-1}$, respectively. There were no significant differences among treatments $(P=0.81)$ at this location. 
treatments increased soybean grain yield from 700 to $1160 \mathrm{~kg} \mathrm{ha}^{-1}$ compared to glyphosate plus DAS, except 5-0$20-13$ at 8.8 and $17.6 \mathrm{~kg} \mathrm{ha}^{-1}$ and $0-0-25-17$ at $17.6 \mathrm{~kg} \mathrm{ha}^{-1}$. This was probably due to increased soybean injury caused by 5-0-20-13 and 0-0-25-17 (Table 4). Yield differences were also related to weed control since glyphosate plus DAS had the lowest control of Palmer amaranth, ivyleaf morningglory, and large crabgrass (Table 4).

At Malden, no significant grain yield differences appeared among treatments $(P=0.81)$. However, 0 $0-62-0$ tended to increase grain yield at the $8.8 \mathrm{~kg} \mathrm{ha}^{-1}$ rate in a weed-free environment (Figure 4(a)), while all $\mathrm{K}$ additives except 3-18-18-0 tended to increase grain yield up to $17.6 \mathrm{~kg} \mathrm{~K} \mathrm{ha}^{-1}$ when combined with glyphosate (Figure 4(b)). Although we did not evaluate soil test chloride, this site's flood irrigation and soybean-rice rotation might have elevated chloride levels. This has been reported in well-irrigated soybean fields in Arkansas where $\mathrm{Cl}$ toxicity reduced yield of certain soybean cultivars [40].

Other studies found no soybean yield benefit when Ncontaining products were applied with glyphosate, and careful fertilizer selection was recommended because fertilizer additives with glyphosate may cause necrosis of the foliage and reduce grain yield [19]. In northern Missouri soybean using single-pass weed management, K-based fertilizer sources such as 3-18-18-0 at 2.2 and $8.8 \mathrm{~kg} \mathrm{ha}^{-1}, 5-0-20-13$ at $2.2 \mathrm{~kg} \mathrm{ha}^{-1}$, and $0-0-62$ at 8.8 and $17.6 \mathrm{~kg} \mathrm{ha}^{-1}$ tank-mixed with glyphosate controlled weeds greater than $90 \%$ (Tables 1 and 2), injured soybean less than $6 \%$, and yielded grain similar to DAS while providing additional $\mathrm{K}$ fertilizer to the plant. However, in southern Missouri using two-pass weed management, weed control was excellent for all additives, and grain yields were similar or greater than glyphosate plus DAS. Some additive yield benefits were observed at Malden when combining glyphosate with $\mathrm{K}$-fertilizer additives under low weed densities, but the benefits were not statistically significant.

\section{Conclusion}

A tank mixture of glyphosate with K-fertilizer additives may provide an economical option for a foliar $\mathrm{K}$ application. Using the correct fertilizer rate is key to minimize injury, maintain effective weed control, and maximize grain yield. Although some fertilizer additives increased concentrations of leaf tissue $\mathrm{K}$, this did not always translate into a yield increase due to the combined effects of increased injury and reduced weed control. Combining K-fertilizers with glyphosate may help offset the application costs of separate fertilizer and herbicide applications; however, applications of $\mathrm{K}$ more consistently increased yield when weeds were controlled. Therefore, farmers may achieve more consistent responses using an overall program of pre-emergence herbicides followed by a glyphosate plus a foliar K-fertilizer, or combining a K-fertilizer with a fungicide application. Additional research is needed to understand the implications of foliar fertilizer selection and crop protection chemical interactions on other nutrients such as $\mathrm{Cu}, \mathrm{B}$, and $\mathrm{S}$ in the soybean plant.

\section{Abbreviations}

DAS: Diammonium sulfate

NIS: Nonionic surfactant.

\section{Nomenclature}

Glyphosate: soybean, Glycine $\max$ (L.) Merr. "Thompson 3999RR and Dyna-Grow 3583 NRR"; common lambsquarters, Chenopodium album L. CHEAL; common ragweed, Ambrosia artemisiifolia L. AMBEL; common waterhemp, Amaranthus tamariscinus Nutt. AMATA; giant foxtail, Setaria faberi Herrm. SETFA; ivyleaf morningglory, Ipomoea hederacea (L.) Jacq. IPOHE; large crabgrass, Digitaria sanguinalis (L.) Scop. DIGSA; Palmer amaranth, Amaranthus palmeri S.Wats. AMAPA.

\section{Acknowledgments}

The authors would like to thank Matthew Jones, Randall Smoot, Sandra Devlin, Matthew Rhine, and Alan Sheckell for their technical assistance in this research. A special thanks is extended to the Missouri Fertilizer and Ag Lime Board for its financial support.

\section{References}

[1] G. Danekas, Missouri Farm Facts, Missouri Agriculture Statistics Service, 2004.

[2] L. P. Gianessi, "Economic and herbicide use impacts of glyphosate-resistant crops," Pest Management Science, vol. 61, no. 3, pp. 241-245, 2005.

[3] J. A. Ivany, "Control of quackgrass with glyphosate and additives," Canadian Journal of Plant Science, vol. 68, pp. 10951101, 1988.

[4] J. D. Nalewaja and R. Matysiak, "Optimizing adjuvants to overcome glyphosate antagonistic salts," Weed Technology, vol. 7, pp. 337-342, 1993.

[5] C. D. Salisbury, J. M. Chandler, and M. G. Merkle, "Ammonium sulfate enhancement of glyphosate and SC-0224 control of Johnsongrass (Sorghum halepense)," Weed Technology, vol. 5, pp. 18-21, 1991.

[6] J. D. Nalewaja and R. Matysiak, "Salt antagonism of glyphosate,” Weed Technology, vol. 39, pp. 622-628, 1991.

[7] E. J. Ehler, J. A. Koscelny, D. C. Heering, D. Wyse-Pester, and P. G. Ratliff, "Technical evaluation of a new potassium salt of glyphosate formulation," Proceeding of North Central Weed Science Society, vol. 58, p. 185, 2003.

[8] V. H. Lengkeek and C. L. Foresman, "New Touchdown formulations from Syngenta Crop Protection," Proceeding of North Central Weed Science Society, vol. 58, p. 186, 2003.

[9] T. C. Mueller, C. L. Main, M. A. Thompson, and L. E. Steckel, "Comparison of glyphosate salts (isopropylamine, diammonium, and potassium) and calcium and magnesium concentrations on the control of various weeds," Weed Technology, vol. 20, no. 1, pp. 164-171, 2006.

[10] P. Fixen, "A national perspective on nutrient management guidelines and regulations," in Proceedings of the Symposium 
on the Status and Basis for Mandating Nutrient Management Guidelines, ASA Annual Meetings, American Society of Agronomy, Madison, Wis, USA, November 2000.

[11] H. F. Reetz and T. S. Murrell, Negligence of Potassium in Corn/ Soybean Systems: Are You Guilty? News \& Views, December Issue, Potash \& Phosphate Institute, Norcoss, Ga, USA, 1998.

[12] P. E. Fixen, "Soil test levels in North America," Better Crops With Plant Food, vol. 86, pp. 12-15, 2002.

[13] R. L. Garcia and J. J. Hanway, "Foliar fertilization of soybeans during the seed-filling period," Agronomy Journal, vol. 68, pp. 653-657, 1976.

[14] M. U. Haq and A. P. Mallarino, "Foliar fertilization of soybean at early vegetative stages," Agronomy Journal, vol. 90, pp. 763769, 1998.

[15] M. U. Haq and A. P. Mallarino, "Soybean yield and nutrient composition as affected by early season foliar fertilization," Agronomy Journal, vol. 92, pp. 16-24, 2000.

[16] A. P. Mallarino, M. U. Haq, D. Wittry, and M. Bermudez, "Variation in soybean response to early season foliar fertilization among and within fields," Agronomy Journal, vol. 93, no. 6, pp. 1220-1226, 2001.

[17] M. B. Parker and F. C. Boswell, "Foliage injury, nutrient intake, and yield of soybeans as influenced by foliar fertilization," Agronomy Journal, vol. 72, pp. 110-113, 1980.

[18] B. L. Vasilas, J. O. Legg, and D. C. Wolf, "Foliar fertilization of soybeans: absorption and translocation of $15 \mathrm{~N}$-labeled urea," Agronomy Journal, vol. 72, pp. 271-275, 1980.

[19] G. D. Binford, B. K. Hearn, M. A. Isaacs, D. J. Hansen, and R. W. Taylor, "Foliar fertilization of roundup ready soybeans," Crop Management. In press.

[20] K. A. Nelson and P. P. Motavalli, "Foliar potassium fertilizer sources affect weed control in soybean with glyphosate," Crop Management. In press.

[21] W. R. Fehr and C. E. Caviness, "Stage of development descriptions for soybeans, Glycine Max (L.) Merrill," Crop Science, vol. 11, Article ID 001118, pp. 929-930, 1971.

[22] K. A. Nelson, P. P. Motavalli, and M. Nathan, "Response of no-till soybean [Glycine max (L.) Merr.] to timing of preplant and foliar potassium applications in a claypan soil," Agronomy Journal, vol. 97, no. 3, pp. 832-838, 2005.

[23] D. D. Buchholz, Soil Test Interpretations and Recommendations Handbook, Division of Plant Sciences, University of Missouri, Columbia, Mo, USA, 2004.

[24] H. A. Mills and J. B. Jones, Plant Analysis Handbook II: a Practical Sampling, Preparation, Analysis, and Interpretation Guide, Micro-Macro, Athens, Ga, USA, 1996.

[25] J. C. Laverty, "A modified procedure for the determination of phosphorus soil extracts," Soil Science Society of America Journal, vol. 27, pp. 360-361, 1963.

[26] D. R. Keeney and D. W. Nelson, "Nitrogen-inorganic forms: indophenol blue method," in Methods of Soil Analysis, Part 2: Chemical and Microbiological Properties, A. Page, R. Miller, and D. Keeney, Eds., vol. 9 of Agronomy, pp. 674-676, American Society of Agronomy, Madison, Wis, USA, 1982.

[27] SAS Institute, "SAS user's guide," SAS Inst., Cary, NC, 2010.

[28] R. O. Kuehl, Statistical Principles of Research Design and Analysis, Duxbury Press, Belmont, Calif, USA, 1994.

[29] K. N. Reddy and R. M. Zablotowicz, "Glyphosate-resistant soybean response to various salts of glyphosate and glyphosate accumulation in soybean nodules," Weed Science, vol. 51, no. 4, pp. 496-502, 2003.

[30] B. G. Young, J. M. Young, J. L. Matthews et al., "Soybean development and yield as affected by three postemergence herbicides," Agronomy Journal, vol. 95, no. 5, pp. 1152-1156, 2003.
[31] L. F. Rader Jr., L. M. White, and C. W. Whittaker, "The salt index-a measure of the effect of fertilizers on the concentration of the soil solution," Soil Science, vol. 55, pp. 201-218, 1943.

[32] K. J. Boote, R. N. Gallaher, W. K. Robertson, K. Hinson, and L. C. Hammond, "Effect of foliar fertilization on photosynthesis, leaf nutrition, and yield of soybeans," Agronomy Journal, vol. 70, pp. 787-791, 1978.

[33] W. D. Poole, G. W. Randall, and G. E. Ham, "Foliar fertilization of soybeans. I. Effect of fertilizer sources, rates, and frequency of application," Agronomy Journal, vol. 75, pp. 195-200, 1983.

[34] G. K. Evanylo and G. W. Zender, "Common ragweed interference in snap beans at various soil potassium levels," Applied Agricultural Research, vol. 4, pp. 101-105, 1989.

[35] S. W. Myers and C. Gratton, "Influence of potassium fertility on soybean aphid, Aphis glycines Matsumura (Hemiptera: Aphididae), population dynamics at a field and regional scale," Environmental Entomology, vol. 35, no. 2, pp. 219-227, 2006.

[36] I. Cakmak, A. Yazici, Y. Tutus, and L. Ozturk, "Glyphosate reduced seed and leaf concentrations of calcium, manganese, magnesium, and iron in non-glyphosate resistant soybean," European Journal of Agronomy, vol. 31, no. 3, pp. 114-119, 2009.

[37] S. P. Conley, L. Abendroth, R. Elmore, E. P. Christmas, and M. Zarnstorff, "Soybean seed yield and composition response to stand reduction at vegetative and reproductive stages," Agronomy Journal, vol. 100, no. 6, pp. 1666-1669, 2008.

[38] N. Bellaloui, R. M. Zablotowicz, K. N. Reddy, and C. A. Abel, "Nitrogen metabolism and seed composition as influenced by glyphosate application in glyphosate-resistant soybean," Journal of Agricultural and Food Chemistry, vol. 56, no. 8, pp. 2765-2772, 2008.

[39] X. Yin and T. J. Vyn, "Critical leaf potassium concentrations for yield and seed quality of conservation-till soybean," Soil Science Society of America Journal, vol. 68, no. 5, pp. 16261634, 2004.

[40] J. C. Rupe, J. D. Widick, W. E. Sabbe, R. T. Robbins, and C. B. Becton, "Effect of chloride and soybean cultivar on yield and the development of sudden death syndrome, soybean cyst nematode, and southern blight," Plant Disease, vol. 84, no. 6, pp. 669-674, 2000. 


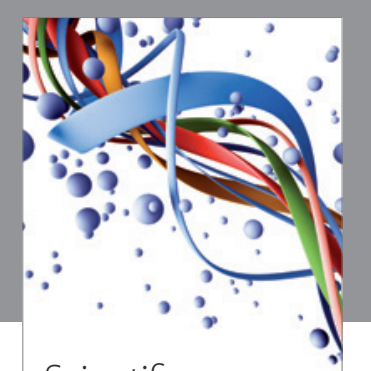

Scientifica
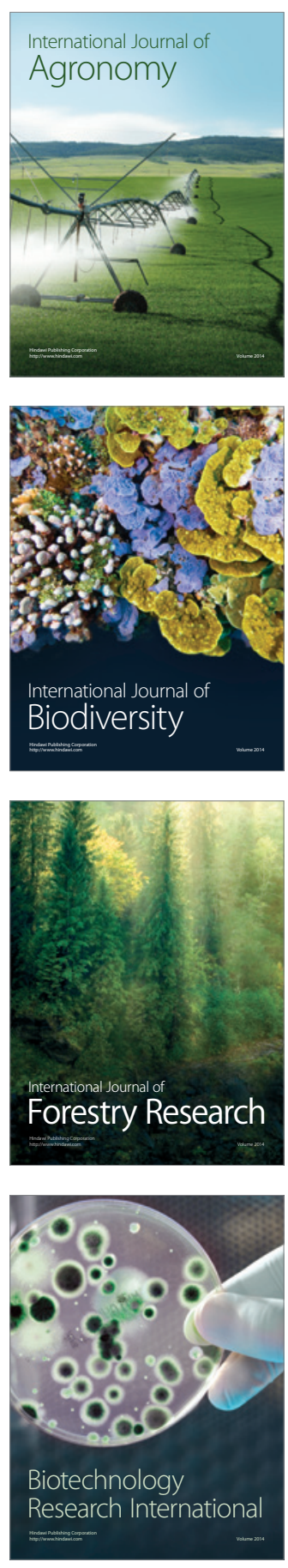
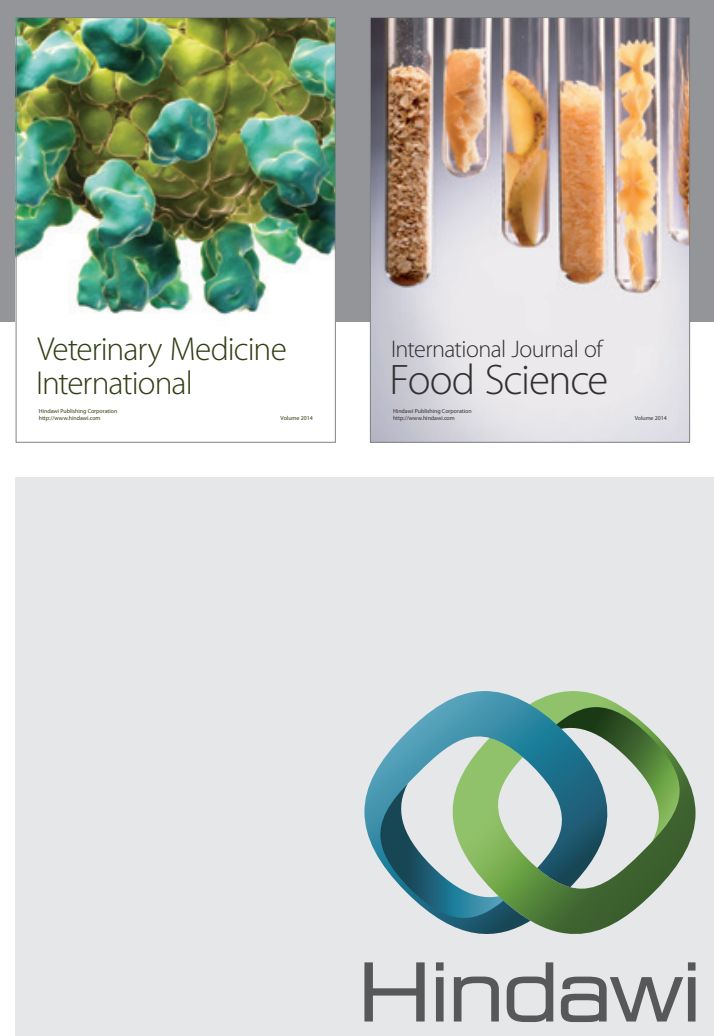

Submit your manuscripts at

http://www.hindawi.com
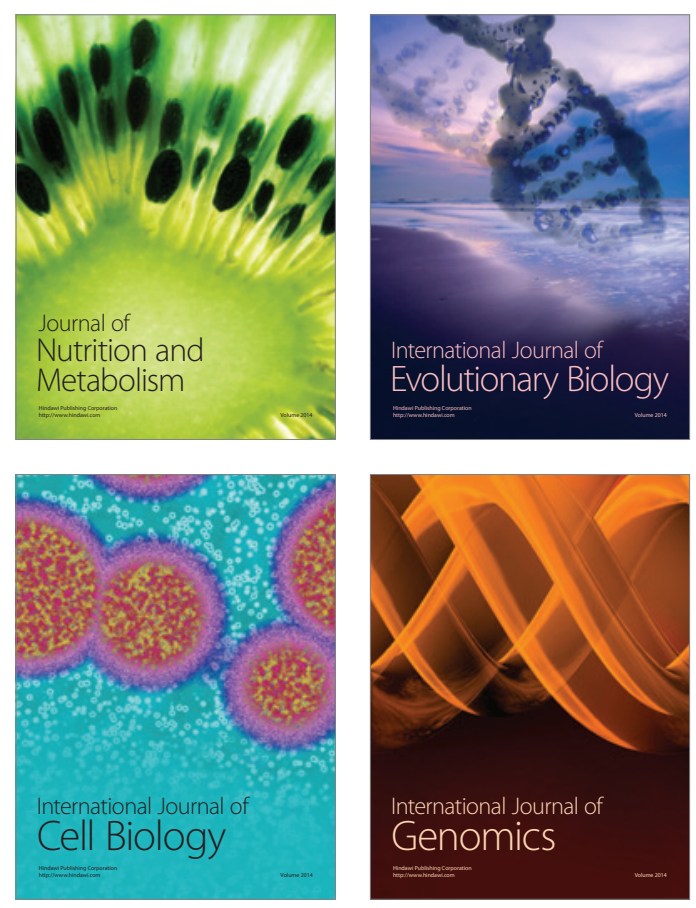
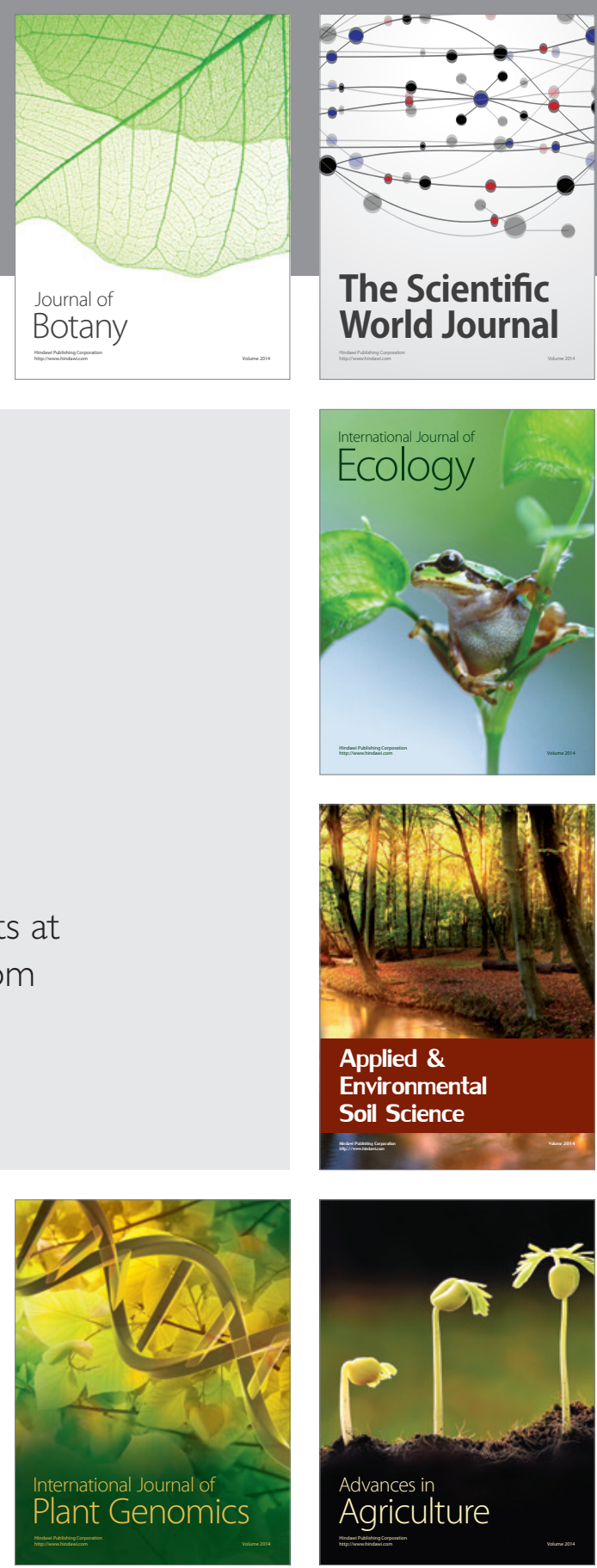

The Scientific World Journal
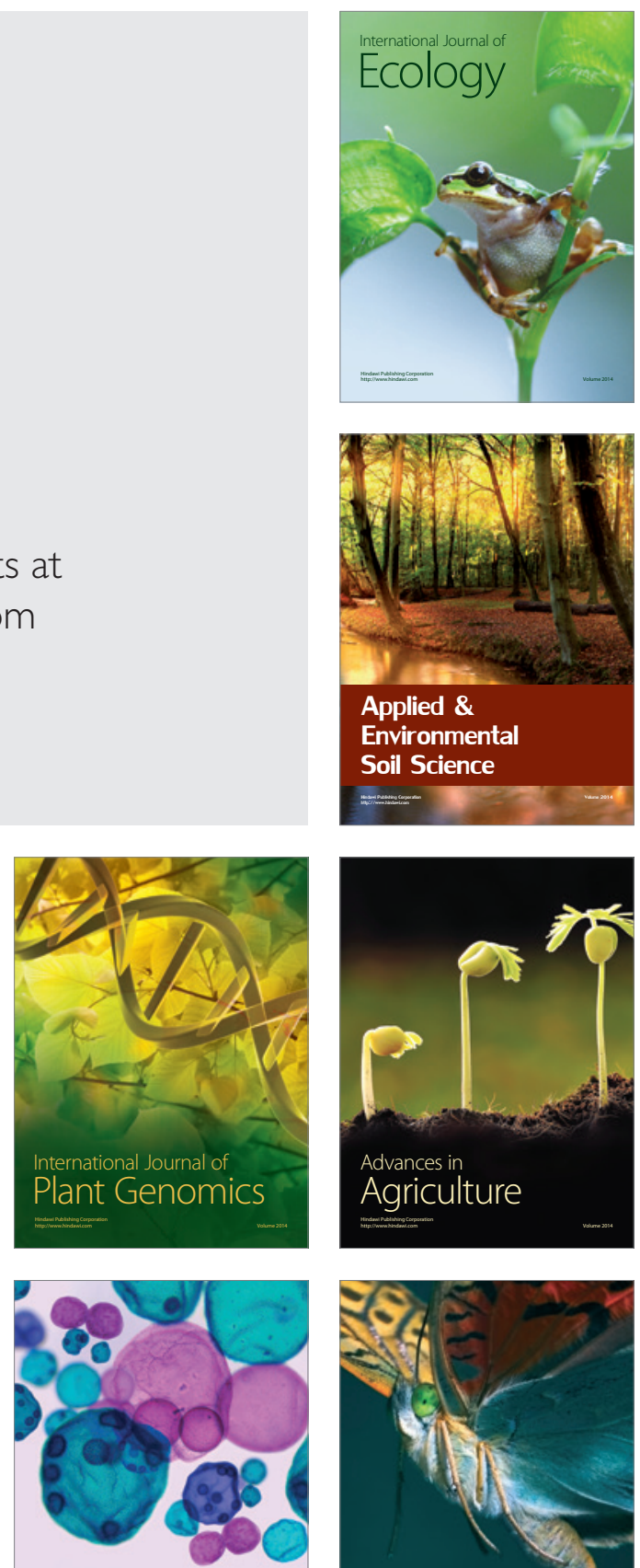

International Journal of Microbiology

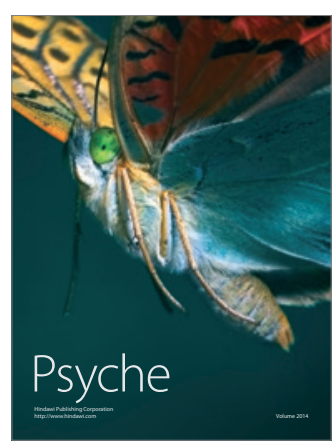

